(C)2007 IEEE. Personal use of this material is permitted. However, permission to reprint/republish this material for advertising or promotional purposes or for creating new collective works for resale or redistribution to servers or lists, or to reuse any copyrighted component of this work in other works must be obtained from the IEEE 


\title{
Compare and Contrast of Contemporary Technical Knowledge Sharing Technologies
}

\author{
Hai Dong, Farookh Khadeer Hussain, Elizabeth Chang \\ Digital Ecosystem and Business Intelligence Institute \\ Curtin University of Technology \\ Perth, Australia \\ Email: \{hai.dong, farookh.hussain, elizabeth.chang\}@cbs.curtin.edu.au
}

\begin{abstract}
Knowledge sharing is not a new topic in knowledge management research field. Many methodologies have been proposed, which aims to exploit the embodied knowledge in practice and transform them to a normal form so that other staffs and organizations can utilize it. In this paper, we propose to compare and contrast the contemporary technical knowledge sharing technologies. We categorize the existing technologies into the implemented and the experimental, and analyze them from multiple perspectives. Conclusion and future work are made in the final section.
\end{abstract}

\section{INTRODUCTION}

Knowledge Sharing (KS) is not a new topic in knowledge management research field. It is well known that the most valuable knowledge within an organization is not limited to the formal documents in the databases and repositories, but also includes the undocumented ideas, insights and know-how of its members [4]. However, this informal and tacit knowledge is deeply rooted in the individual experience and the culture of work community. To solve these problems, many methodologies have been proposed, which aims to exploit the embodied knowledge in practice and transform them to a normal form, so that other staffs and organizations can utilize it. KS is one of these methods to solve the above problems.

In this paper, we propose to compare and contrast the contemporary technical KS technologies. The literature of KS concerning definitions and benefits are reviewed in Section 2. In Section 3 we analyze the implemented KS technologies and experimental KS technologies from multiple perspectives. The conclusion and future work are made in Section 4.

\section{KNOWLEDGE SHARING LITERATURE REVIEW}

Recently many researchers start to recognize the importance defining KS and thus KS has been defined theoretically. In 2003, Cummings stated that KS involves 'the process through which knowledge is channeled between a source and a recipient' and its meaning within an organization is 'an organization that obtains access to its own and other organization's knowledge' [10]. In the same year, Soekijad and Andriessen considered KS involves the processes of knowledge creation, knowledge transfer and knowledge distribution [16]. Ryu et al. defined KS as "the behavior of disseminating one's acquired knowledge with other members within one's organization" [17]. In 2006, Jones et al. defined $\mathrm{KS}$ as "the sharing of knowledge about business processes and the related knowledge required to make these processes work" [8]. Here I present the definition of KS - the process of translating the personalized knowledge into the collective knowledge, which consists of the processes of knowledge discovery, knowledge extraction and knowledge transfer. Following that, the main activities of KS are described. Here Cummings summarized three types of main KS activities, including those focused on 'accessing the form and embeddedness of the knowledge', those focused on 'establishing and managing an administrative structure through which differences and issues between the parties can be accommodated and reduced' and those focused on 'transferring knowledge' [10].

Then why use KS? From UTS's webpage (http://inus.socs.uts.edu.au/), we can identify the most common quoted advantages for KS. The first benefit is that KS can create 'newer and better products and services', which means 'ways of combining information are evaluated to see if new products and services can be easily produced'. The second benefit is experience transfer, which the experiential knowledge is the 'information stored as to how individual tasks were done in the past'. The following advantage is organizational learning, which whole organization is able to learn about the information that is kept about 'how things were done in the past'. The final advantage is transactional knowledge that is about 'where the knowledge is'. Without the capacity for sharing knowledge, no business organizations can utilize the specialized resources and capabilities of its members, nor can it co-produce new knowledge. Thus, $\mathrm{KS}$ is a critical factor in terms of its relative competitiveness.

\section{TECHNOLOGICAL METHODOLOGIES FOR KS}

Current researches on $\mathrm{KS}$ technology can be divided into two aspects - technical and cultural. From technical perspective, researchers studied multiple methodologies implementing $\mathrm{KS}$, such as virtual library [1], Internet listservers [3], multi-agent architecture [5], on-line question posing and peer-assessment [13] and knowledge portal [11]. We will analyze the implemented and experimental KS technologies respectively. 


\section{A. Implemented KS technologies}

As we mentioned above, $\mathrm{KS}$ is not a new topic in the research field. Currently many technologies are being implemented in the purpose of sharing knowledge. In this section, we will introduce and compare the characteristics of these implemented technologies.

Virtual library is an innovative technology to store electronic resource online, which can be utilized as an efficient methodology to share knowledge [1]. Fujiu introduces the implementation of virtual library in the field of pharmaceutical research. The resources stored in the library are the patents and the references from e-journals and databases. By means of the library, the researchers may share such information in a knowledge platform. In addition, the virtual library has the function of automatically detecting duplication of such information, which may simplify the volume of resources.

Gene Ontology (GO) is used to describe the profiles of gene products. Camon et al. introduced the Gene Ontology Annotation (GOA) database, which supports the up-to-date annotations to UniProt knowledge base, which is the largest protein sequence annotation database in the world. GOA usually utilizes the manual way and electronic way to convert the UniProt entries to the GO. In addition, by building the dynamic references to multiple databases, GOA tries to keep the latest biological information [2].

Internet listservers (IL), which are programs that automatically send e-mails to a list of subscribers, could be used as an efficient KS tool to promote the corporation in different fields. Guerin introduces the usage of IL in the field of environmental monitoring in soil contamination and remediation, which contains the listservers for bioremediation discussion, Phytonet, Phytoremediation, groundwater and environmental forensics. They discover the moderators, which manage the mail list, are essential to control the participation and quality [3].

Nardon and Moura introduce an ontology-based KS system combined with the deductive database technology utilized in the field of healthcare. By means of RDF (Resource Description Framework) standard, which is a W3C coding standard, the UMLS (Unified Medical Language System) ontology is represented. In which, is the most comprehensive medical ontology in the world. In addition, the ontology uses the TRI-DEDALO (TRIples, DEduction, DAta and LOgic) system, which is a deductive database to query the data from the knowledge base. Finally, by a case of Brazilian National Health Card, the authors explain the function of UMLS ontology and the deductive database [6].

A network organization is a group of people who organize themselves for the common purpose. Considering that the network organization usually consists of people who are geographically dispersed and with different background, KS becomes problematic when they attempt to solve the complex problems. Santoro et al. introduces and analyses a collaborative environment - GAIN (Goal Action Information Network), which comprises a website, a document management system and KS mechanisms to solve the above issues. By means of a case study, the authors analyze the contribution of GAIN to KS in network organizations [7].

Knowledge portal is "the means of access to the corporate information and application". Baalen, Bloemhof and Heck address the role of knowledge portal in emerging network of practice. A 'network of practice' is to set up a virtual place (e.g. knowledge portal) to meet each other, share information and knowledge. These deal with governmental and policy issues, and seeks financial resources. The central question is "how a knowledge portal facilitates the diffusion of knowledge among rather loosely coupled and often disconnected innovation projects". Here the authors reviewed the literatures about KS, emerging network of practice and formulate the conceptual model of knowledge portal. By a case study in agro-logistic innovation project, the result indicates the role of knowledge portal in a network of practice [11].

Rafaeli et al. introduce an online KS system for education resources - QSIA (Question Sharing and Interactive Assignment). In this system, by means of test and assignment, QSIA enables online-learning, which is the major method of KS. In addition, QSIA also involves question, answer and recommendation sharing. The conceptual model of QSIA is shown in Fig.1 [12].

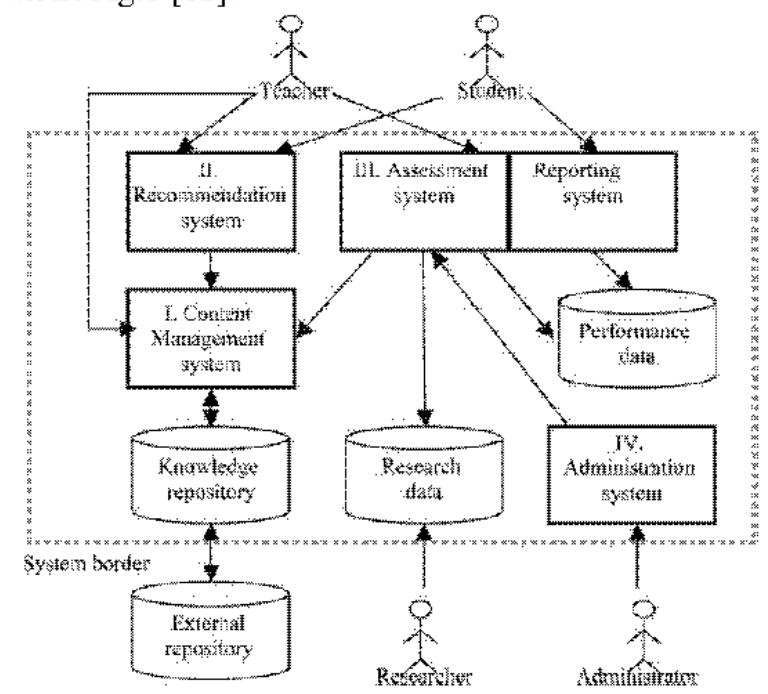

Fig.1 QSIA online system intemal structure

Barak and Rafaeli introduce an integrated technology combing QSIA (Question Sharing and Interactive Assignment) system and QPA (Question-Posing Assignment) system for online learning, which is a major style for KS. In the integrated system, students are asked to contribute questions about their study and rank peers' questions. By a case study in e-business course in MBA, the outcome of the system is evaluated [13].

In the following sections, we compare and contrast the implemented knowledge sharing technologies in the respects of domain, based technology, approved in practice, problems, and 
solutions, advantages and limitations. The results are shown in Table 1 and Table 2.

TABLE 1

COMPARE AND CONTRAST OF THE IMPLEMENTED KNOWLEDGE SHARING TECHNOLOGIES (PART 1)

\begin{tabular}{|c|c|c|c|c|}
\hline & Yirfual Library & GOA & Inter met Listserver & $\begin{array}{c}\text { Ontology } \\
\text { Dedective Database }\end{array}$ \\
\hline Domain & $\begin{array}{l}\text { Pharmacevitical } \\
\text { fesearch }\end{array}$ & Bicinformatics & $\begin{array}{l}\text { Eavironimental } \\
\text { inonit toring }\end{array}$ & Heat theare \\
\hline $\begin{array}{l}\text { Based } \\
\text { technology }\end{array}$ & $\begin{array}{l}\text { Endinote se twate } \\
\text { and compostor } \\
\text { network }\end{array}$ & $\begin{array}{l}\text { Gene oftology i } \\
\text { Lniprot } \\
\text { knowledgebase }\end{array}$ & Lisiservar & $\begin{array}{l}\text { RDF, UMLS \& TRI- } \\
\text { DEDALO datgbase }\end{array}$ \\
\hline $\begin{array}{l}\text { Appreved in } \\
\text { practice }\end{array}$ & Yes & Yes & Yes & Yes \\
\hline $\begin{array}{l}\text { Problems (if } \\
\text { possible) }\end{array}$ & None & None & $\begin{array}{l}\text { If histservers are not } \\
\text { thanaged propetly, } \\
\text { they may generate } \\
\text { jank mats. }\end{array}$ & None \\
\hline $\begin{array}{l}\text { Soluticins (if } \\
\text { possible) }\end{array}$ & None & None & $\begin{array}{l}\text { Froperty mangging } \\
\text { and sel acting } \\
\text { listserver as nsers" } \\
\text { needs. }\end{array}$ & Nenz \\
\hline Advantages & $\begin{array}{l}\text { Conveni ant for ussars: } \\
\text { improwing the } \\
\text { efficiency of } \\
\text { academic research }\end{array}$ & $\begin{array}{l}\text { Conizining most } \\
\text { compr hhensive and } \\
\text { up-to-date } \\
\text { inf ormation in the } \\
\text { gene fieid; frien illy } \\
\text { user interface for } \\
\text { querying inforinaticn }\end{array}$ & 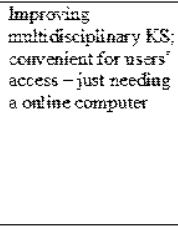 & 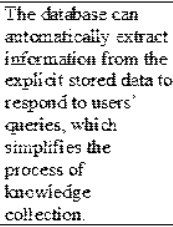 \\
\hline Limitations & 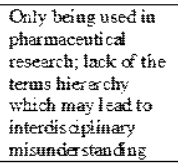 & $\begin{array}{l}\text { Only being used in } \\
\text { the gene field; }\end{array}$ & $\begin{array}{l}\text { Lack of the terms } \\
\text { hierarchy may leads } \\
\text { to the } \\
\text { inter dsciplinary } \\
\text { misunderstanding }\end{array}$ & $\begin{array}{l}\text { only being used in } \\
\text { the experimentas } \\
\text { stage without } \\
\text { practice; limited in } \\
\text { heaftheare } \\
\text { organizations }\end{array}$ \\
\hline
\end{tabular}

TABLE 2

COMPARE AND CONTRAST OF THE IMPLEMENTED KNOWLEDGE SHARING TECHNOLOGIES (PART 2)

\begin{tabular}{|c|c|c|c|c|}
\hline & $\begin{array}{c}\text { Coliaborative } \\
\text { Emironment - } \\
\text { GAIN }\end{array}$ & Krow fedge Portal & QSIA & QSIA \& QPA \\
\hline Domain & $\begin{array}{l}\text { Network } \\
\text { organisation }\end{array}$ & Agriculturat industy & Education freld & Education fíeld \\
\hline $\begin{array}{l}\text { Based } \\
\text { technology }\end{array}$ & $\begin{array}{l}\text { Wobsite design: } \\
\text { document } \\
\text { manag iment sy stem } \\
\text { \& KS michanism }\end{array}$ & Knowiedge potal & $\begin{array}{l}\text { My SQL, JSP \& } \\
\text { open sonrce } \\
\text { appiicafion server }\end{array}$ & $\begin{array}{l}\text { My SQL, } 3 S P \& \\
\text { open source } \\
\text { appliczion serva }\end{array}$ \\
\hline $\begin{array}{l}\text { Approved in } \\
\text { practice }\end{array}$ & Yas & Yes & Yes & Yes \\
\hline $\begin{array}{l}\text { Probleats sif } \\
\text { possibley }\end{array}$ & None & $\begin{array}{l}\text { No direct effort to } \\
\text { tacit KS; no ärect } \\
\text { effont to the } \\
\text { reciprocity of } \\
\text { kniawledge exchange } \\
\text { among projects }\end{array}$ & $\begin{array}{l}\text { Issue of user } \\
\text { identification in } \\
\text { exams; isolating } \\
\text { some students; users' } \\
\text { confusi on to the } \\
\text { system; secutity and } \\
\text { privacy problems; } \\
\text { insufficient facilities } \\
\text { support; time } \\
\text { constuning; tecinical } \\
\text { foilture }\end{array}$ & $\begin{array}{l}\text { Students are iess } \\
\text { active to assess } \\
\text { peers' questicns; } \\
\text { most students cannot } \\
\text { acte QSIA as a } \\
\text { teamwoth tool. }\end{array}$ \\
\hline $\begin{array}{l}\text { Solutions (if } \\
\text { possible) }\end{array}$ & None & $\begin{array}{l}\text { Research } \\
\text { phepositicns ñteed to } \\
\text { be tested. }\end{array}$ & None & $\begin{array}{l}\text { Propety using pee: } \\
\text { assessmentit. }\end{array}$ \\
\hline Advantages & $\begin{array}{l}\text { Improving KS in } \\
\text { network } \\
\text { organisations }\end{array}$ & 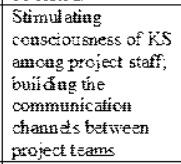 & $\begin{array}{l}\text { Improwing } \\
\text { knowledge leating, } \\
\text { sharing and } \\
\text { assessing. }\end{array}$ & $\begin{array}{l}\text { Most students enioy } \\
\text { QSIA as thet: } \\
\text { assessment tool; } \\
\text { impreving online } \\
\text { learning. }\end{array}$ \\
\hline Limitations & 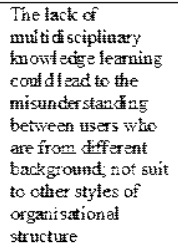 & $\begin{array}{l}\text { The test resuit is not } \\
\text { able to prove the } \\
\text { irect effect of } \\
\text { knowledge ports on } \\
\text { kS. }\end{array}$ & $\begin{array}{l}\text { QSIA uses matching } \\
\text { mechanista which } \\
\text { matches } \\
\text { tecommenders and } \\
\text { encuiress, which is } \\
\text { tiot snitable for } \\
\text { aiml ess visitors: } \\
\text { himited in the fiel d of } \\
\text { education. }\end{array}$ & $\begin{array}{l}\text { Simited in the fieid } \\
\text { of education; QSIA } \\
\text { cannot improve peer } \\
\text { cooperation. }\end{array}$ \\
\hline
\end{tabular}

According to the compare and contrast of above technologies in Table 1 and Table 2, we can see the implementation of KS technologies has spread over multiple domains, which reveals the huge commercial potential in this field. The technologies, which these KS methodologies base are various, including network techniques, databases, ontologies, Java and so on. Most technologies are proven in practice, by means of actual implementation or tests in case studies. Most technologies do not find any problems in the process of implementation. Although some issues are found in some technologies, the related remediation is given. Every technology basically realizes their functions in their own domain. The common disadvantage of these technologies is that they all lack the multidisciplinary knowledge hierarchies, which determines that they are not able to be utilized in other fields. Thus, we can conclude that these technologies are wellfunctioned, domain-specific KS approaches.

\section{B. Experimental KS technologies}

Apart from the used technologies, some new KS methodologies are invented and in the experimental phase. In this section, we will introduce some innovative KS methodologies and compare them.

Abu Yaman and Kerckhoffs propose a multi-agent system for sharing experimental data about wastewater treatment plant, which is based on the CLIPS (C Language Integrated Production System) that supports a complete environment for rules and object based expert system. By means of this system, users may access to the internet to share the data files from the CLIPS system [5].

Li et al. propose an agent-based buddy finding technology, which is utilized for online KS among people with similar interests. By means of the agents, people can find the available buddies based on their own portfolios. The authors use the fuzzy-set theory to access the buddy membership. They empirically evaluate the buddy-finding system by a music selection scenario. The test result shows that the agents can work as well as human subjects in finding music buddies [9].

Roda et al. present an agent-based system designed to support the adoption of KS practices within communities. The system is based on a conceptual fram ework, by modeling the adoption of knowledge management practices as a change process. It is identified that pedagogical strategies are best suited to support users through the various stages of the adoption process. The resulting community-based system provides each member of the community with an artificial personal change-management agent capable of guiding users in the acquisition and adoption of new KS practices by activating personalized and contextualized intervention [15].

Sumi and Mase attempt to build a communityware system by presenting a project of providing digital assistants to support participants in an academic conference. Participants were provided with a personal assistant system with mobile and ubiquitous computing technologies that facilitated communication among the participants in the conference. They 
also made online services available via the Web to encourage the participants to continue their relationships even after the conference. They show the system provided for the project and report the results [14].

According to the compare and contrast of above technologies in Table 3, we can see the experimental KS technologies trend to promote KS in broader scope, which seems to be more practical. Most inventions adopt the latest technologies, such as PDA and agent technology. Owing to the reason that these technologies are barely proposed, most of them are still in the experimental phase and out of practice. The common advantages of these inventions are that they are closer to our real life and have nice commercial potential. In addition, researchers increasingly focused on utilizing KS technologies on multiple fields. However, these technologies need to be validated in practice.

Compared with the existing technologies, the new technologies tend to be more practical to the public, multidisciplinary and with huge commercial potential, which is a positive change in the KS field.

TABLE 3

COMPARE AND CONTRAST THE EXPERIMENTAL KNOWLEDGE SHARING TECHNOLOGIES

\begin{tabular}{|c|c|c|c|c|}
\hline & Mniti-zgent System & $\begin{array}{c}\text { Baddy- findiag } \\
\text { System }\end{array}$ & Agent-based Systew & $\begin{array}{c}\text { Conference } \\
\text { Assistamt System }\end{array}$ \\
\hline $\begin{array}{l}\text { Domain } \\
\text { Based } \\
\text { fechnology }\end{array}$ & $\begin{array}{l}\text { Rrastewater } \\
\text { tratment } \\
\text { CLIS, Clanguage, } \\
\text { agent techrology }\end{array}$ & $\begin{array}{l}\text { Casnat } \\
\text { Agent tecinotogy, } \\
\text { fuzzy reasoning } \\
\text { mechanism } \\
\text { No }\end{array}$ & $\begin{array}{l}\text { Commrnities } \\
\text { R-InCACKnowi=ige- } \\
\text { Intelligent } \\
\text { Conversational } \\
\text { Agenss) } \\
\text { ho }\end{array}$ & $\begin{array}{l}\text { Academic } \\
\text { conferences } \\
\text { Web server, LAN, } \\
\text { Java, Peri, PDA and } \\
\text { C++ } \\
\text { Yes }\end{array}$ \\
\hline $\begin{array}{l}\text { Approved in } \\
\text { practice }\end{array}$ & ANs & & & \\
\hline Advantages & $\begin{array}{l}\text { Conveni int for } \\
\text { users'access - caly } \\
\text { need a conimuter } \\
\text { online } \\
\text { Not bren testedin } \\
\text { practice; domain- } \\
\text { specific }\end{array}$ & $\begin{array}{l}\text { Close to real fife and } \\
\text { has nice commer ciat } \\
\text { future } \\
\text { Not bean tested if } \\
\text { practice }\end{array}$ & $\begin{array}{l}\text { Improsing users' KS } \\
\text { awareuess } \\
\text { Thot been tested in } \\
\text { paractic= }\end{array}$ & $\begin{array}{l}\text { PDA brings the } \\
\text { convenience and } \\
\text { flexibinty of } \\
\text { communicaten. } \\
\text { No restut show s the } \\
\text { disect effort to KS. }\end{array}$ \\
\hline
\end{tabular}

\section{CONCLUSION AND FUTURE WORKS}

In this paper, we review the contemporary primary research outcomes in the field of KS. We divide the researches into the implemented KS methodologies and the experimental KS methodologies from the perspective of application. By comparing and contrasting the domain, based technologies, approved in practices, problems, solutions, advantages and disadvantages of eight implemented technologies and four newly created technologies. We found that the former functions are well in their own domain but lacks the cross-field $\mathrm{KS}$ cooperation and the latter tends to be more multidisciplinary but also lacks persuasive validation process. The general trend of technological KS methodology research is more close to our real life and has higher comm ercial potential.

In general, these literatures represent the situation of the current KS researches. By critically analysing the papers, it is observed that the positive changes are occurring in $\mathrm{KS}$ researches, which tends to be multidisciplinary, cross-field, more universal and closer to our life, with highest research potential and commercial values. Thus, we believe that the future $\mathrm{KS}$ researches can recognize the issues stated in our paper and self-improvement according to the general trend we present.

\section{ACKNOWLEDGMENT}

We would like to express our gratitude to the assistance of DEBII and School of Information Systems in Curtin University of Technology.

\section{REFERENCES}

[1] M. Fujiu (2004) Virtual Library: a Knowledge Sharing System in Pharmaceutical Research. Yakugaku Toshokan, 49(2): 146-152.

[2] E. Camon, M. Michele, B. Daniel, L. Vivian, D. Emily, M. John, B. David, H. Nicola, L. Rodrigo \& A. Rolf (2004) The Gene Ontology Annotation (GOA) Database: Sharing Knowledge in Uniprot with Gene Ontology. Nucleic Acids Research, Vol. 32.

[3] T. F. Guerin (2001) Environmental Monitoring in Soil Contamination and Remediation Programs: How Practitioners are using the Internet to Share Knowledge. Joumal of Environmental Monitoring, 3(3): 267-273.

[4] D. Bobrow \& J. Whalen (2002) Community Knowledge Sharing in Practice: The Eureka Story. Journal of the Society for organization learning and MIT Press, 4(2).

[5] R. I. K. Abu Yaman \& E. J. H. Kerckhoffs (1998) A Multi-agent Architecture for Sharing Knowledge and Experimental Data about Waste Water Treatment Plants Through the Internet'. Dirasat: Natural and Engineering Sciences, 25(2): 316-325.

[6] F. B. Nardon \& L. A. Moura (2004) Knowledge Sharing and Information Integration in Healthcare Using Ontologies and Deductive Database. Medinfo, 11(1): 62-66.

[7] F. M. Santoro, M. R. S. Borges \& E. A. Rezende (2006) Collaboration and Knowledge Sharing in Network Organizations. Expert Systems with Applications.

[8] M. C. Jones, M. Cline \& S. Ryan (2006) Exploring Knowledge Sharing in ERP Implementation: an Organizational Culture Framework. Decision Support Systems, 41(2): 411-434.

[9] X. Li, A. R. Montazemi \& Y. Yuan (2005) Agent-based Buddy-finding Methodology for Knowledge Sharing. Information \& Management.

[10] J. Cummings (2003) Knowledge Sharing: A Review of the Literature.

[11] P. V. Baalen, J. Bloemhof-Ruwaard \& E. V. Heck (2005) Knowledge Sharing in an Emerging Network of Practice: The Role of a Knowledge Portal. European Management Journal, 23(3): 300-314.

[12] S. Rafaeli, M. Barak, Y. Dan-Gur \& E. Toch (2004) QSIA - a Webbased Environment for Learning, Assessing and Knowledge Sharing in Communities. Computers \& Education, 43(3): 273-289.

[13] M. Barak \& S. Rafaeli (2004) On-line Question-posing and Peerassessment as Means for Web-based Knowledge Sharing in Learning. International Joumal of Human-Computer Studies, 61(1): 84-103.

[14] Y. Sumi \& K. Mase (2002) Conference Assistant System for Supporting Knowledge Sharing in Academic Communities. Interacting with Computers, 14(6): 713-737.

[15] C. Roda, A. Angehrn, T. Nabeth \& L. Razmerita (2003) Using Conversational Agents to Support the Adoption of Knowledge Sharing Practices. Interacting with Computers, 15(1): 57-89.

[16] M. Soekijad \& E. Andriessen (2003) Conditions for Knowledge Sharing in Competitive Alliances. European Management Journal, 21(5): 578587.

[17] S. Ryu, S. H. Ho \& I. Han (2003) Knowledge Sharing Behaviour of Physicians in Hospitals. Expert Systems with Applications, 25(1):113-122. 